\title{
The influence of socio-cultural characteristics on commercialization of smallholder dairy value chain development in Uasin Gishu County, Kenya
}

\author{
Moses Ageya Kembe ${ }^{1 *}$, Charles Ochola Omondi ${ }^{2}$ and George Godwin Waga ${ }^{1}$ \\ ${ }^{1}$ School of Planning and Architecture, Maseno University, Private Bag, Maseno University, Kenya. \\ ${ }^{2}$ School of Environment and Earth Sciences, Maseno University, Private Bag, Maseno, Kenya.
}

Received 21 March 2016; Accepted 11 May, 2016

\begin{abstract}
Livelihoods of many rural households in the developing economies majorly depend on smallholder farming activities. Smallholder dairy farming is the single largest component of agriculture in Kenya. Uasin Gishu County is the leading milk producer in Kenya with subsistence, semi-commercialized and commercialized farmers constituting 70, 20 and 10\%, respectively. Smallholder dairy farming in Kenya grows at $4.1 \%$ per annum compared to $1.2 \%$ for agriculture as a whole. Commercializing smallholder dairy value chain is therefore important in providing pathway out of poverty, and for sustainable rural development. Commercialization of smallholder dairy value chain development is variable and is not yet developed enough in the scale of commercialization index to enable producers benefit from increased income to stimulate rural development. This may be because of the influences of Socio-cultural characteristics of the smallholder producers. The objective of this study is to find out the influence of socio-cultural characteristics on commercialization of smallholder dairy value chain development. Social survey research design was used to obtain both secondary and primary data. A sample size of 384 smallholder dairy producers was studied out of a total population of 50,457 respondents. Data analysis procedures used in this study includes: mean, standard deviation, Pearson correlation coefficient, Spearman's rank correlation coefficient and multiple regressions. The results of this study showed that the socio-cultural characteristics of smallholder dairy producers have significant influence on the commercialization of smallholder dairy value chain development.
\end{abstract}

Key words: Commercialization, smallholder dairy producers, smallholder dairy value chain development, sociocultural characteristics, Uasin Gishu County.

\section{INTRODUCTION}

Globalization, urbanization, migration and rising per capita income trends are some of the forces that drive changes in consumption behavior towards high value agriculture. These trends create market niches for commodities such as fresh fruits, vegetables, processed and semi-processed maize meal and dairy products (Omiti et al., 2006). These intensification enhancing interventions need to be considered in the context of

*Corresponding author. E-mail: manerakem@yahoo.co.uk.

Author agree that this article remain permanently open access under the terms of the Creative Commons Attribution License 4.0 International License 
producers' ability. The dairy sector is one of the critical agricultural sub-sectors in Common Market for East and Southern Africa (COMESA) and East Africa Community (EAC) countries, with high potential for improving food security and welfare of families. These increasing market opportunities for dairy production represents exciting challenges and opportunities for improving food security, income generation and employment in COMESA and EAC countries (GoK, 2010a). The EAC countries have more than 100 million people, whose demand for food and dairy products is always rising due to increasing urbanization and awareness among population on good nutrition in the families.

Dairy farming in Kenya is the single largest component of agriculture. It grows at $4.1 \%$ per annum compared to $1.2 \%$ for agriculture as a whole (IFAD, 2015). Furthermore, it accounts for $3.5 \%$ of the total gross domestic product (GDP), and $14 \%$ of agricultural GDP (IFAD, 2015). Moreover, dairy farming is dominated by smallholder producers (80\%), and produce about $80 \%$ of total milk production and $70 \%$ of the total milk marketed in the Kenya (IFAD, 2015; GoK, 2010a).

Kenya National Dairy Master Plan (GoK, 2010a) which is consistent with the agricultural sector development strategy (ASDS), 2010 to 2020 and the Kenya Vision 2030 aims to transform the prevalent subsistence smallholder dairy farming to competitive, commercial and sustainable dairy value chain that will lead to economic growth, poverty alleviation, wealth creation and employment. Commercializing smallholder dairy farming is an indispensable pathway towards sustainable rural development for most developing countries relying on the dairy farming as an important pathway out of rural poverty (GoK, 2010a; Ele et al., 2013).

The main purpose of subsistence system is to produce, and to maintain household food self-sufficiency by using mainly non-traded and household generated inputs. The semi-commercial system is focused towards generation of marketable surplus and maintaining household food security by using both traded and non-traded farm inputs. In commercial system, profit maximization is the main motive of the entrepreneur and inputs are predominantly obtained from markets (Ele et al., 2013; Hall, 2005). Poulton et al. (2008) defines agricultural commercialization as an agricultural transformation process in which farmers shift from mainly consumptionoriented subsistence production towards market- and profit-oriented production systems. Commercialization of smallholder dairy value chain development usually takes a long transformation process from subsistence to semicommercial, and then to fully commercialized dairy farming (Jaleta et al., 2009; GoK, 2010a; Agwu et al., 2013).

Smallholder farming is paramount to livelihoods of many rural households in developing economies. Smallholder dairy producers with the knowledge of determinants of competitiveness may benefit from the improvements in their technical performance to generate higher incomes. Inadequate access to market may also influence intensification in terms of poor access to modern inputs and credit, poor infrastructure, inadequate access to markets, and limited access to modern technologies (Kibiego et al., 2015). Thus, it is not possible for the smallholder dairy producers to integrate with the market, and enjoy the benefits of commercialization smallholder dairy value chain development unless the socio-cultural characteristics of the producers influencing market access are addressed

During the period up to 1969, the dairy industry operated as an open market with various independent dairies being active market participants, while between 1969 and 1992 and primarily due to the rationalisation of the dairy industry by the Government, a monopolistic market situation was created. By mid-1992 to date, the Government liberalised the industry (GoK, 2010a, 2013b).

In Kenya small holder dairy farming is characterized by poorly developed market linkages and unreliable market outlets due to a number of factors including pronounced seasonal fluctuations in milk output and prices, poor rural infrastructure (roads and electricity), as well as the lack of management and business skills and inefficiencies in the post-harvest segment of the milk value chain. Kenya has an extensive formal marketing network comprising large milk processors and dairy cooperatives, and even larger informal market where smallholder dairy producers and small scale milk traders make direct sales of milk to consumers. About $80 \%$ of milk currently marketed in Kenya goes through informal channels in which smallholder producers and traders dominate (IFAD, 2015). The informal sector dominance is mainly due to an inefficient processing sector and consumer preference for raw milk which is cheaper.

The smallholder dairy producers in Uasin Gishu County are categorized in the commercialization process as: $70 \%$ are subsistence, $20 \%$ are semi-commercialized and $10 \%$ are commercialized (GoK, 2013a). This indicates that the commercialization of smallholder dairy value chain development is variable, and is not yet developed enough to enable producers benefit from increased income and stimulate rural development (GoK, 2010a; GoK, 2013a). This may be influenced by socio-cultural characteristics (Cefer et al., 2014; Boogaarda et al., 2006). The Country and the Uasin Gishu County also have huge untapped potential for commercial-orientation of smallholder dairy value chain development (GoK, 2010a; GoK, 2013a; GoK, 2013c).

\section{METHODOLOGY}

\section{Area of study}

Uasin Gishu County is situated in the former Rift Valley Province 
with a total area of $3,327.8 \mathrm{Km} 2$. It extends between longitude $34 \epsilon^{\circ} 50^{\prime}$ and $35^{\circ} 37^{\prime}$ east and $0^{\circ} 03^{\prime}$ and $0^{\circ} 55^{\prime}$ north. It is made up of six Sub-Counties namely: Soy; Turbo; Kapsaret; Kesses; Ainabkoi and Moiben (GoK, 2013a). The county is the leading milk producing county in Kenya with three (3) categories of dairy producers namely: subsistence $(70 \%)$, semi-commercialized (20\%) and commercialized (10\%) (GoK, 2013a; GoK, 2013c). The County therefore, is mainly characterized by subsistence oriented smallholder dairy producers.

\section{Research design and method of data analysis}

The study used cross-sectional research design. Methods of data analysis includes: Descriptive statistics, namely mean and standard deviation; inferential statistics namely; correlations and regression namely Pearson, spearman's rho and multiple regression respectively. The model given below was used to examine the dependence structure between random variables:

$Y=\beta_{0}+\beta_{1} X_{1}+\beta_{2} X_{2}+\ldots+\beta_{n} X_{n}+\varepsilon$

Where: $\mathrm{Y}=$ Average $\mathrm{HCl}$ (Dependent variable). variables)

$\mathrm{X}_{\mathrm{i}-\mathrm{n}}=$ socio-cultural characteristics (Independent

$\beta_{0}=$ Constant or Point of intercept on $Y$ axis

$\beta_{1}-n=$ Regression coefficients.

$\varepsilon \quad=$ Residual term or the error

The degree of commercialization of smallholder dairy value chaindevelopment was measured using Household Commercialization Index $(\mathrm{HCl})$ given by the formula below:

$\mathrm{HCI}=\left[\frac{\text { Gross value of milk sales per household per month }}{\text { Gross value of total milk production per household per month }}\right] \times 100$

The household commercialization index $(\mathrm{HCl})$ measures the extent to which household production is oriented towards the commercialization. It ranges from zero to $100 \%$. A value of zero signifies a totally subsistence oriented producer. The closer the index is to $100 \%$, the higher the degree of commercialization (Nmadu et al., 2012; Muhammad-Lawal et al., 2014). $\mathrm{HCl}$ was applied in this study in measuring the dependent variable. This study used dairy milk production and dairy milk sales in measuring $\mathrm{HCl}$ of the households of smallholder dairy producers. This (Jaleta et al., 2009; Zhou et al., 2013; Poulton et al., 2008; MuhammadLawal et al., 2014) provides scale of commercialization $(\mathrm{HCl})$ as: 0 to $30 \%$, subsistence oriented farmer:31 to $65 \%$, semicommercialized farmers: $66 \%$ and commercialized farmers $100 \%$.

\section{RESULTS AND DISCUSSIONS}

\section{Descriptive results}

The socio-cultural characteristics of the producers are analyzed using descriptive statistics (Table 1). The proportions of respondents as per their level of access to knowledge and technology are as follows:

$59.4 \%$ of the respondents had men alone accessing knowledge and technology, $29.1 \%$ both man and woman, and $11.5 \%$ had woman alone.

This means that most of the producers had man alone accessing knowledge and technology. This makes the respondents who are women notable effectively to access the markets due to lack of knowledge and technology. The proportions of respondents as per their level of access to assets are as follows:

$21.1 \%$ of the respondents had men alone accessing assets, $74 \%$ both man and woman, and $4.9 \%$ had woman alone.

This implies that most of the respondents had both man and woman accessing productive assets. The proportions of respondents as per their level of education are as follows:

$44 \%$ of the producers had reached secondary level education, $20.9 \%$ diploma/certificate level, $13.8 \%$ primary level of education and $4.6 \%$ had adult literacy education.

This shows that most of the respondents (81.6\%) had attained secondary level of education and above. 95.4\% of the respondents had attained primary level of education and above. This makes the respondents to be able to access the markets through access to market information. The proportions of respondents as per their level of control of income by gender are as follows:

$65 \%$ of the respondents had men alone controlling income, $26.7 \%$ both men and women, and $8.3 \%$ had women alone.

This suggests that most of the respondents had men alone controlling income. The proportions of respondents as per their level of control of assets by gender are as follows:

$74.9 \%$ of the respondents had men alone controlling assets, $16.8 \%$ both men and women, and $8.3 \%$ had women alone.

This means that most of the respondents had men alone controlling assets. The proportions of respondents as per their decision making on dairy aspects by gender are as follows:

$67.2 \%$ of the respondents had men alone making decision on dairy aspects, $16.4 \%$ both men and women, and $16.4 \%$ had women alone.

This suggests that men alone dominated in decision making on dairy aspects. The proportions of respondents as per the age of the household head are as follows: 
Table 1. Descriptive results of Social- cultural characteristics.

\begin{tabular}{|c|c|c|c|}
\hline Access to knowledge and technology by gender & Frequency & Valid percent & Cumulative percent \\
\hline Man alone & 222 & 59.4 & 59.4 \\
\hline Both man and woman & 110 & 29.1 & 70.9 \\
\hline Woman alone & 43 & 11.5 & 100 \\
\hline Total & 384 & 100 & - \\
\hline \multicolumn{4}{|l|}{ Access to assets by gender } \\
\hline Man alone & 79 & 21.1 & 21.1 \\
\hline Both man and woman & 284 & 74 & 78.9 \\
\hline Woman alone & 21 & 4.9 & 100 \\
\hline Total & 384 & 100 & - \\
\hline \multicolumn{4}{|l|}{ Level of education of the house hold head } \\
\hline Adult literacy education & 18 & 4.6 & 4.6 \\
\hline Primary & 53 & 13.8 & 18.4 \\
\hline Secondary & 169 & 44 & 62.4 \\
\hline Diploma/ Certificate level & 66 & 20.9 & 83.3 \\
\hline Graduate level training & 64 & 16.7 & 100 \\
\hline Total & 384 & 100 & - \\
\hline \multicolumn{4}{|l|}{ Control of income by gender } \\
\hline Man alone & 243 & 65 & 65 \\
\hline Both man and woman & 101 & 26.7 & 35 \\
\hline Woman alone & 40 & 8.3 & 100 \\
\hline Total & 384 & 100 & - \\
\hline \multicolumn{4}{|l|}{ Control of assets by gender } \\
\hline Man alone & 280 & 74.9 & 74.9 \\
\hline Both man and woman & 63 & 16.8 & 25.1 \\
\hline Woman alone & 41 & 8.3 & 100 \\
\hline Total & 384 & 100 & - \\
\hline \multicolumn{4}{|l|}{ Decision making on dairy aspects by gender } \\
\hline Man alone & 261 & 67.2 & 67.2 \\
\hline Both man and woman & 63 & 16.4 & 32.8 \\
\hline Woman alone & 60 & 16.4 & 100 \\
\hline Total & 384 & 100 & - \\
\hline \multicolumn{4}{|l|}{ Age of respondents in years } \\
\hline $25.00-35.00$ & 40 & 10.4 & 10.4 \\
\hline $36.00-45.00$ & 128 & 33.3 & 43.7 \\
\hline $46.00-55.00$ & 153 & 39.9 & 83.6 \\
\hline $56.00-65.00$ & 51 & 13.1 & 96.7 \\
\hline Above 65 years & 12 & 3.3 & 100 \\
\hline Total & 384 & 100 & - \\
\hline \multicolumn{4}{|l|}{ Land ownership by respondents } \\
\hline Family land/inheritance & 163 & 44.5 & 44.5 \\
\hline Own purchased land & 200 & 52.5 & 55.5 \\
\hline Leased land & 21 & 3 & 100 \\
\hline Total & 384 & 100 & - \\
\hline
\end{tabular}


Table 1. Cont'd.

\begin{tabular}{lccc}
\hline Religion of respondents & & & \\
Catholics & 69 & 18 & 18 \\
Protestants & 302 & 78.6 & 82 \\
Others & 13 & 3.4 & 100 \\
Total & 384 & 100 & - \\
& & & \\
Born in community by respondents & & & 64.6 \\
Yes & 248 & 64.6 & 35.4 \\
No & 136 & 35.4 & - \\
Total & 384 & 100 & \\
\hline
\end{tabular}

Table 2. Correlation results of socio-cultural characteristics.

\begin{tabular}{clcc}
\hline \multirow{2}{*}{$\mathbf{S} \mathbf{N}$} & Independent variable & \multicolumn{2}{c}{ Correlation Model } \\
\cline { 3 - 4 } & & Pearson Correlation & Spearman's rho \\
\hline 1 & Access to knowledge and technology & $0.940^{* *}$ & $0.813^{\star *}$ \\
2 & Access to assets & $0.875^{* *}$ & $0.890^{* *}$ \\
3 & Level of education & $0.820^{* *}$ & $0.826^{* *}$ \\
4 & Control of income & $-0.733^{* *}$ & $-0.691^{* *}$ \\
5 & Control of Assets & $-0.695^{\star *}$ & $-0.721^{* *}$ \\
6 & Decision making & $0.680^{* *}$ & $0.600^{* *}$ \\
7 & Age & $-0.600^{* *}$ & $-0.525^{* *}$ \\
8 & Land ownership & $0.501^{*}$ & $0.616^{*}$ \\
9 & Religion & $0.045^{*}$ & $0.067^{*}$ \\
10 & Born in the community & $-0.498^{*}$ & $-0.375^{\star}$ \\
\hline
\end{tabular}

** Correlation is significant at the 0.01 level (2-tailed); *Correlation is significant at the 0.05 level (2-tailed); Sample size, $\mathrm{N}=384$; Correlation between each variable and itself $=1.00$.

$10.4 \%$ of the respondents were the ages of $25-35$ years while majority of the producers $(73.2 \%)$ were $36-55$ years of age.

This implies that fewer youth are involved in dairy farming. The proportions of respondents as per their land ownership were as follows:

$44.5 \%$ of the producers had family land/inheritance, $52.5 \%$ had purchased land, and $3.0 \%$ had leased land.

This means that most of the producers had purchased their land. The proportions of respondents as per their religion are as follows:

$18 \%$ of the respondents were Catholics, $78.6 \%$ were Protestants, and $3.4 \%$ were others.

This implies that most of the respondents were Protestants. The proportions of respondents as per their being born in the community are as follows:

$64.6 \%$ of the respondents born in the community, whereas $35.4 \%$ were migrants.

This means that most of the respondents were born in the community.

\section{Inferential results}

The correlation and regression analysis are used to test the association between socio-cultural characteristics of respondents and commercialization of smallholder dairy value chain development using the household commercialization index (Tables 2, 3 and 4).

The correlation coefficients in Table 2 indicate that the household commercialization index of the respondents is significantly correlated with the socio-cultural characteristics (independent variables). However, some 
Table 3. Regression results of socio-cultural characteristics.

\begin{tabular}{lccc}
\hline Independent variable & Coefficient & Std. error & T-ratio \\
\hline Access to knowledge and technology & $0.208^{\star *}$ & $(0.215)$ & 0.967 \\
Access to assets & $0.190^{\star *}$ & $(0.179)$ & 1.061 \\
Level of education & $0.148^{\star *}$ & $(0.125)$ & 1.184 \\
Control of income & $-0.108^{\star *}$ & $(0.110)$ & -0.982 \\
Control of Assets & $-0.105^{\star *}$ & $(0.092)$ & -1.141 \\
Decision making & $0.095^{\star *}$ & $(0.078)$ & 1.218 \\
Age & $-0.085^{\star *}$ & $(0.069)$ & -1.232 \\
Land ownership & $0.026^{*}$ & $(0.026)$ & 1.000 \\
Religion & $0.014^{*}$ & $(0.004)$ & 3.500 \\
Born in the community & $-0.019^{*}$ & $(0.071)$ & -0.268 \\
Cons & 0.285 & $(0.633)$ & 0.450 \\
\hline
\end{tabular}

** Coefficient is significant at the 0.01 level (2-tailed); * Coefficient is significant at the 0.05 level (2-tailed); Sample size, $N=384$. $R=0.880 ; R^{2}=0.774 ;$ adjusted $R^{2}=0.687$.

Table 4. Household commercialization index $(\mathrm{HCl})$ results for Socio-cultural characteristics.

\begin{tabular}{|c|c|c|c|}
\hline Access to knowledge and technology by gender & Frequency & Valid percentage & $\begin{array}{c}\text { Average household commercialization } \\
\text { index }\end{array}$ \\
\hline Man alone & 222 & 59.4 & 29 \\
\hline Both man and woman & 110 & 29.1 & 58 \\
\hline Woman alone & 43 & 11.5 & 26 \\
\hline Total & 384 & 100 & 37.7 \\
\hline \multicolumn{4}{|l|}{ Access to assets by gender } \\
\hline Men alone & 79 & 21.1 & 24 \\
\hline Both Men and Women & 284 & 74 & 28 \\
\hline Women alone & 21 & 4.9 & 23 \\
\hline Total & 384 & 100 & 25 \\
\hline \multicolumn{4}{|l|}{ Level of education of house hold head } \\
\hline Adult literacy education & 18 & 4.6 & 26 \\
\hline Primary & 53 & 13.8 & 28 \\
\hline Secondary & 169 & 44 & 29 \\
\hline Diploma /Certificate & 66 & 20.9 & 48 \\
\hline Graduate level training & 64 & 16.7 & 69 \\
\hline Total & 384 & 100 & 40 \\
\hline \multicolumn{4}{|l|}{ Control of income by gender } \\
\hline Men alone & 243 & 65 & 27 \\
\hline Both Men and Women & 101 & 26.7 & 68 \\
\hline Women alone & 40 & 8.3 & 25 \\
\hline Total & 384 & 100 & 40 \\
\hline \multicolumn{4}{|l|}{ Control of assets by gender } \\
\hline Men alone & 280 & 74.9 & 25 \\
\hline Both Men and Women & 63 & 16.8 & 52 \\
\hline Women alone & 41 & 8.3 & 23 \\
\hline Total & 384 & 100 & 33.3 \\
\hline
\end{tabular}


Table 4. Cont'd.

\begin{tabular}{lccc} 
Decision making on dairy aspects by gender & & & \\
Men alone & 261 & 67.2 & 24 \\
Both Men and Women & 63 & 16.4 & 21 \\
Women alone & 60 & 16.4 & 35.3 \\
Total & 384 & 100 & 29 \\
& & & 60 \\
Age of respondents in years & & & 28 \\
$25.00-35.00$ & 40 & 10.4 & 23 \\
$36.00-45.00$ & 128 & 33.3 & 21 \\
$46.00-55.00$ & 153 & 39.9 & 53.7 \\
$56.00-65.00$ & 51 & 13.1 & \\
Above 65 years & 12 & 3.3 & 20 \\
Total & 384 & 100 & 23 \\
& & & 36.7 \\
Land ownership by respondents & 163 & 44.5 & \\
Family land/inheritance & 200 & 52.5 & 22 \\
Own purchased land & 21 & 3 & 53 \\
Leased land & 384 & 100 & 20 \\
Total & & & 31.7 \\
Religion of respondents & & & \\
Catholics & 69 & 18 & 25 \\
Protestants & 302 & 78.6 & 55 \\
Others & 13 & 3.4 & 40 \\
Total & 384 & 100 & \\
& & & \\
Born in community by respondents & & 64.6 & \\
Yes & 248 & 100 & \\
No & 136 & & \\
Total & 384 & & \\
\hline
\end{tabular}

correlations were more powerful statistically at $1 \%$ level of significance than the others at $5 \%$ level. Access to knowledge and technology, access to assets, level of education, control of income, decision making and age have correlation coefficients greater than 0.5 (+ or -), and they are significant at $99 \%$ confidence level. On the other hand, land ownership, religion and born in the community have low Pearson coefficients of $0.501,0.045$ and -0.498 respectively at $\alpha=0.05$. The regression coefficients show that these socio-cultural characteristics influence the household commercialization index. Access to knowledge and technology, access to assets, level of education and decision making on dairy aspects were found to have positive relationship with $\mathrm{HCl}$ and highly significant at $1 \%$. Control of income, control of assets and age of the producers on the other hand had negative relationship with $\mathrm{HCl}$ and highly significant at $1 \%$. Land ownership and religion had positive relationship with $\mathrm{HCl}$ but significant at $5 \%$. Born in the community had negative relationship with $\mathrm{HCl}$ but significant at $5 \%$.

Capital $R(0.880)$ is the multiple correlation coefficients that tell us how strongly the multiple independent variables are related to the dependent variable. The $R$ Square statistics (0.774) means that the ten independent variables (social cultural variables) in the regression model account for $77.4 \%$ of the total variation in the given $\mathrm{HCl}$. The higher the R-squared statistic, the better the model fits the data. In this case, the model fits data with a high significance considering there are lots of other variables not in our model which influence $\mathrm{HCl}$.

The $\mathrm{HCl}$ of the respondents were determined, and the results are indicated in Table 4 . The $\mathrm{HCl}$ ranges from level of $25 \%$ (subsistence) to level of $53.7 \%$ (semicommercialized). The results of correlations, regressions and $\mathrm{HCl}$ of socio-cultural characteristics shown in Tables 2, 3 and 4 respectively explain the following: 


\section{Access to knowledge and technology}

Correlation results of a Pearson correlation coefficient of 0.940 and Spearman's rho of 0.813 shows that there is positive relationship between respondent's access to knowledge and technology, and the average household commercialization index. The coefficients are highly significant at $1 \%$. Similarly, in Table 3, regression results shows that access to knowledge and technology has a standardized coefficient of 0.208 meaning that access to knowledge and technology is positively associated with household commercialization index, and coefficient is highly significant at $1 \%$. A unit (one percent) increases of level of access to knowledge and technology causes an increase of $\mathrm{HCl}$ by $0.208(20.8 \%)$. Respondents who were only men having access to knowledge and technology had an average $\mathrm{HCl}$ of $29 \%$, and in cases where only women had access they had $\mathrm{HCl}$ of $26 \%$. In the cases where both men and women had access to knowledge and technology, the $\mathrm{HCl}$ was $58 \%$. The results therefore show that for higher commercialization index to be achieved in dairy farming, both genders should access knowledge and technology in increasing dairy production and access to markets for higher $\mathrm{HCl}$.

This study finding is confirmed by the results obtained by Farinde and Taiwo (2003) that one of the biggest challenges to the stakeholders involved in the process of agricultural transformation in Sub-Saharan Africa is the high percentage (70 to $80 \%$ ) of women responsible for household food production. Until recently, women were usually excluded from variety of services such as access to inputs, and they were neglected by agricultural extension services. In addition, some institutional arrangements such as market contractual agreements were exclusively for male-headed households. Femaleheaded households are therefore expected to have lower commercialization indexes compared to their male counterparts. The results are in line with that of Ochola et al. (2003) on culture, traditions and society. The results also conform to that of Tangka et al. (1999) on women and sustainable development of market-oriented dairying in East Africa.

According to Kurosaki (2003), demand for modern technologies promote the input side of production and facilitate the development and advancement of technological innovations. The use of modern technologies can result in higher productivity and production entering markets. Jaleta et al. (2009) found that specialized production leads to higher productivity through greater learning by doing, scale economies, exposure to new ideas through trade (better knowledge diffusion through exchange), and also better incentives in the form of higher income. The household-level technological changes can help to secure food selfsufficiency under a risky food-market environment.

The importance of resource-saving and high-enhancing technological innovations and their adoption by the ultimate users are unquestionable in smallholder commercialization process (Jeleta et al., 2009; Amoako, 2003). Adopting a temporal perspective, they argued that, in the short-run, increased commercialization could occur without change in agricultural technologies, but the inverse would be less likely due to the indispensable demand-side pull for technological innovations. The findings also conform to that of Omiti et al. (2006) that remoteness restrict access to information about technologies and changing prices, leaving the rural smallholders unable to respond to changes in market incentives.

According to Kariuki in the Standard Newspaper, Friday May 8, 2015, expanding on knowledge strengthens one's qualifications, present high value to the company due to acquired knowledge and helps one to stay marketable. Today's job market is stiff calling for employee to expand on their skills and knowledge to stay relevant, competitive and be in a better position for jobs in different market segments. Limited knowledge and skills are the major issues affecting access to employment and income generating opportunities.

\section{Access to assets}

According to correlation results of a Pearson correlation coefficient of 0.875 and Spearman's rho of 0.890 it shows that there is a positive relationship between respondent's access to assets, and the average household commercialization index. The coefficients are highly significant at $1 \%$. Similarly, regression results show that access to assets has a standardized coefficient of 0.190 meaning that high level access to assets is positively associated with higher household commercialization index and, coefficient is highly significant at $1 \%$. A unit (one percent) increases of level of access to assets causes an increase of $\mathrm{HCl}$ by $0.190(19 \%)$. The $\mathrm{HCl}$ of respondents where both men and women were accessible to assets is highest (28\%), whereas in cases where men alone had access to assets have $\mathrm{HCl}$ of $24 \%$ and for women alone had the lowest $\mathrm{HCl}(23 \%)$. Involvement of both genders in commercialization is very crucial. This is because the respondents are able to invest in dairy production jointly for higher dairy productivity and $\mathrm{HCl}$. Men and women should all become agents of positive change and sustainable development in the society.

The results conform to that of Heierli and Gass (2001) who argue that assets empower the rural poor by increasing their incomes and make them less vulnerable to shocks, and the extent of vulnerability determines household commercialization index. Highly vulnerable households are expected to have lower commercialization index. Relatively well endowed with agricultural capital have high potential of commercializing. 
The acquisition and ownership of productive assets can pave the way for household to participate in economic activities. Households with relatively higher production levels have higher probability

of market participation and commercialization.

According to Jayne et al. (2012), improving access to land among the land-constrained smallholder households would be a seemingly effective way to reduce poverty, as a very small incremental addition to land access is associated with a large relative rise in commercialization and consequently in income. Gebreselassie and Sharp (2008) found out in their study that coefficient for land is statistically significant at $1 \%$ while the coefficient for oxen ownership is relatively high but significant only at the $5 \%$.

\section{Level of education}

Correlation results of a Pearson correlation coefficient of 0.820 and Spearman's rho of 0.826 shows that there is positive relationship between respondent's level of education and the average household commercialization index. The coefficients are highly significant at $1 \%$. Similarly, regression results shows that level of education has a standardized coefficient of 0.148 meaning that high level of education is positively associated with higher household commercialization index and, coefficient is highly significant at $1 \%$. A unit (one percent) increases of level of education causes an increase of $\mathrm{HCl}$ by 0.148 (14.8\%). The results show that $\mathrm{HCl}$ level increases with the increase of education levels. Respondents with graduate level of training have the highest level of commercialization (69\%); primary level have $28 \%$; secondary level have $29 \%$; diploma/certificate level have $48 \%$ whereas those with adult literacy education have the lowest commercialization level (26\%). This is because the respondents with higher level of education are able to increase their dairy productivity through access to knowledge and technology, and access to market through access of market information among others issues of marketing.

Education is an important tool to escape poverty, but only if the education system reaches the right people with the right content (Heierli and Gass, 2001). Intellectual capital as captured by education is hypothesized to play a positive role in influencing market participation and $\mathrm{HCl}$. Level of education gives an indication of the household ability to process information and causes some producers to have better access to understanding and interpretation of information than others. High education level is important, as it is likely to lead to the reduction of search, screening and information costs. However, the expectation may be reversed when there are competing and more remunerative employment opportunities available in the area that require skills that are enhanced by more education (Lapar et al., 2003).

Education also makes the producers to access market information, and be able to engage in trade effectively. Gebreselassie and Sharp (2008) found out in his study that coefficient for literacy of the household head is positive and significant, which implies a high probability of better production among farm households with an educated head (compared to households with illiterate heads). According to Simonyan et al. (2010), education would significantly enhance producers' ability to make accurate and meaningful decisions. They also opined that level of education raises human capital and increases their level of managerial abilities which is an incentive for commercialization. Nmadu et al. (2012) found out that age of producers, marital status, educational status, number of years in poultry production, type of birds and system of production increased technical efficiency and $\mathrm{HCl}$ of commercial poultry farmers. Ele et al. (2013) found out that on average, a household head is married and has between 19 and 22 years of farming experience, and has had at least a primary school education, which indicates that they can at least read and write, an important factor in the commercialization of farming. Human capital elements such as education, experience, skills, capabilities and talents of family members are essential in commercializing smallholder agriculture. There are some individuals who inherently have better skills and capabilities to do the implicit cost-benefit analyses required and apply their talents to quickly adapt to and exploit new opportunities (Jaleta et al., 2009).

\section{Control of income}

According to correlation results of a Pearson correlation coefficient of -0.733 and Spearman's rho of -0.691 which shows that there is a negative relationship between respondent's control of income, and the average household commercialization index. The coefficients are highly significant at $1 \%$. Similarly, in Table 3 , regression results shows that control of income has a standardized coefficient of -0.108 meaning that high level of control of income by one gender is negatively associated with lower household commercialization index and, coefficient is highly significant at $1 \%$. A unit (one percent) increases of level of control of income by one gender causes a decrease of $\mathrm{HCl}$ by $0.108(10.8 \%)$.

According to $\mathrm{HCl}$ results, households where income is controlled by both men and women, the commercialization level was highest $(68 \%)$ and was lowest where income is controlled by only women $(25 \%)$. In cases where income was controlled by men alone, $\mathrm{HCl}$ was $27 \%$. This is because the money generated and controlled by both men and women is reinvested in the dairy for increased productivity hence higher $\mathrm{HCl}$. Jaleta et al. (2009) reported that the impact of smallholder commercialization on the gender dimension depends on the commodity's gender specific labor demand and on who controls the income generated. The shift from staple 
maize to sugarcane production in Kenya and the Philippines was associated with a significant reduction in the percentage of women's labor use in agricultural activities, from 50.5 to $1.2 \%$ in Kenya and from 9.1 to $2.5 \%$ in the Philippines. However, in Guatemala, the shift from maize to vegetable production increased the proportion of women's labor use from 6.1 to $21.5 \%$. Whatever proportion of female labor is involved in cash crop production, income from these crops is usually controlled by men.

\section{Control of assets}

Pearson correlation coefficient of -0.695 and Spearman's rho of -0.721 show that there is negative relationship between respondent's control of assets and the average household commercialization index. The coefficients are highly significant at $1 \%$. Similarly, regression results show that control of assets has a standardized coefficient of -0.105 meaning that high level of control of assets by one gender is negatively associated with lower household commercialization index and, coefficient is highly significant at $1 \%$ (Table 3). A unit (one percent) increases of level of control of assets by one gender causes a decrease of $\mathrm{HCl}$ by $0.105(10.5 \%)$. Results of $\mathrm{HCl}$ indicate that respondents where assets were controlled by both men and women has commercialization index of $52 \%$; in cases of men alone $\mathrm{HCl}$ was $25 \%$ and where assets were controlled only by women, commercialization index was $23 \%$. This is due to the fact that joint control of productive assets by both gender empowers them to increase the dairy productivity and access to markets hence increased $\mathrm{HCl}$.

\section{Decision making on dairy aspects}

According to the earlier mentioned correlation results of a Pearson correlation coefficient of -0.680 and Spearman's rho of -0.600 it shows that there is negative relationship between respondent's decision making on dairy aspects, and the average household commercialization index. The coefficients are highly significant at $1 \%$. Similarly, in Table 3, regression results show that decision making on dairy aspects has a standardized coefficient of -0.095 meaning that there was a highly significant negative relationship between respondent's decision making on dairy aspects, and the average household commercialization index and, coefficient is highly significant at $1 \%$. A unit (one percent) increases of level of decision making on dairy aspects by one gender causes a decrease of $\mathrm{HCl}$ by $0.095(9.5 \%)$. Results of $\mathrm{HCl}$ indicate that respondents where decision making on dairy aspects was made by both men and women has commercialization index of $61 \%$; men alone was $24 \%$ and in cases where decision making was made only by women, commercialization index is $21 \%$. This is because women are also important agents in decision making on commercialization of smallholder dairy value chain development process. The findings are in line with those of Manfre et al. (2013) on reducing the gender gap in Agricultural extension and advisory services. How to find the best fit for men and women

\section{Age of respondents in years}

As shown earlier, correlation results of a Pearson correlation coefficient of -0.600 and Spearman's rho of 0.525 shows that there is a negative relationship between respondent's age, and the average household commercialization index. The coefficients are highly significant at $1 \%$. Similarly, regression results show that age of respondents head has a standardized coefficient of -0.085 (Table 3 ) meaning that respondent head is negatively associated with household commercialization index and, coefficient is highly significant at $1 \%$. A unit (one percent) increases of age of respondent head causes a decrease of $\mathrm{HCl}$ by 0.085 (8.5). According to $\mathrm{HCl}$ results, respondents of 36 to 45 years old have higher commercialization index (highest $\mathrm{HCl}$ of $60 \%$ ) and respondents of 65 years and above have lower commercialization index (lowest $\mathrm{HCl}$ of $21 \%$ ). The other respondents had $\mathrm{HCl}$ results as follows: $25-35$ years had $29 \%$; $46-55 \%$ had $28 \%$ and $56-65 \%$ had $23 \%$. The results are due to the fact that relatively young respondents are more commercial-oriented than older ones. This is because young respondents have high level of education and are able to access information and technology for increased dairy productivity and market access.

According to Nmadu et al. (2012), age of farmers among others characteristics increased technical efficiency and $\mathrm{HCl}$. Randela et al. (2008) reported that the relationship with age is expected to be negative depending on the stages of development. Younger farmers are expected to be progressive, more receptive to new ideas and to better understand the benefits of agricultural commercialization. In addition, relatively young farmers usually have higher socio-economic status that, inter alia, enables them to be faced by lower transactions costs. Younger farmers also have higher levels of education and contact with outside world. In most cases, older farmers view farming as a way of life rather than as business and have strong emotional or almost biological connection with farming and land.

\section{Land ownership}

Correlation results earlier mentioned of a Pearson correlation coefficient of 0.501 and Spearman's rho of 0.616 shows that there is a positive relationship between respondent's ownership of land, and the average household commercialization index. The coefficients are 
significant at $5 \%$. Likewise, regression results show that ownership of land has a standardized coefficient of 0.026 meaning that owning land is positively associated with higher household commercialization index and, coefficient is significant at $5 \%$. A unit (one percent) increases of owning land causes increase of $\mathrm{HCl}$ by $0.026(2.6 \%)$. According to $\mathrm{HCl}$ results, respondents with own purchased land have higher commercialization index of $67 \%$ and whereas respondents with family /inherited land have lower commercialization index of $20 \%$. The one with leased land have $\mathrm{HCl}$ of $23 \%$. This is because respondents who purchase land have high potential and capacity to maximally utilize the available land thereby obtaining higher productivity and $\mathrm{HCl}$.

Randela et al. (2008) reported that access to arable land is a necessary condition for market participation. The larger the size of a arable land a household uses, the higher the production levels are likely to be, and the higher the probability of market participation and $\mathrm{HCl}$. Gebreselassie and Sharp (2008) found out that land and oxen, which could also be used as proxies for capital stock, are found to be important in explaining the variation in the level of production his sampled households. The coefficient for land is statistically significant at $1 \%$ whereas the coefficient for oxen ownership is relatively high but significant only at the $5 \%$ level.

\section{Religion of the household}

According to correlation results of a Pearson correlation coefficient of 0.045 and Spearman's rho of 0.067 which shows that there is a positive relationship between respondent's religion and the average household commercialization index. The coefficient is significant at $5 \%$. Similarly, regression results show that religion of the respondent has a standardized coefficient of 0.014 , meaning that religion has positive influence on the household commercialization index and, coefficient is significant at $5 \%$. A unit (one percent) change in religion causes increase of $\mathrm{HCl}$ by $0.014(1.4 \%)$. The $\mathrm{HCl}$ results show that respondents who were Protestants have higher commercialization index of $53 \%$ whereas those who were from Catholics have $\mathrm{HCl}$ of $22 \%$, and those from other denominations have lower commercialization index of $20 \%$. The results therefore mean that respondents from protestants have some exposure to knowledge and technology for dairy production and market access compared to those from other denominations.

\section{Born in the community}

According to correlation results of a Pearson correlation coefficient of -0.498 and Spearman's rho of -0.375 it shows that there is a negative relationship between producers being born in the community, and the average household commercialization index. The coefficients are significant at $5 \%$. Similarly, regression results show that being born in the community has a standardized coefficient of -0.019 meaning that being born in the community has negative influence on the household commercialization index and, coefficient is significant at $5 \%$. A unit (one percent) change being born in the community causes reduction of $\mathrm{HCl}$ by $0.019(1.9 \%)$. The results above show that respondent who were migrants have higher commercialization index of $55 \%$ and whereas those who were born in the community have lower commercialization index of $25 \%$. This is mainly as result of migrants being more commercial oriented than those born in the community. In the new environment, migrants have little social networks which force them to work hard to improve their livelihoods hence higher $\mathrm{HCl}$.

This result is similar to the one of Randela et al. (2008) that found out that farmers born in the same community have low level of commercialization compared to the migrants who have little social support and networks. This makes the migrants to work hard to enhance their livelihood through increased market participation and $\mathrm{HCl}$. The result is also supported by information obtained from both key informants and focused group discussion that migrants are more pro-commercialization compared to those born in the community. This is because the drive for migrants is mainly commercial orientation while drive for those born in the community is normally business as usual. The result is also in line with the findings of Holt, (2009) that individuals often become entrepreneurs by being thrown into situations that force them to fashion their own means of economic livelihoods. Immigrants fit this model. Circumstances afford few options for these persons who frequently establish independent ventures.

\section{CONCLUSION AND RECOMMENDATIONS}

Based on the study results, the socio-cultural characteristics of smallholder dairy producers particularly access to knowledge and technology; access to assets by gender; access to education; control of income by gender; control of assets; decision making on dairy aspects and age in years have highly significant influence on commercialization of smallholder dairy value chain development. In view of these results, the National and County Governments should formulate policies, strategies, projects and programs that may encourage access to knowledge and technology and assets by both men and women for increased level of commercialization; enforce access to education to all citizens and ensure that all sexes have control of income and assets for increased commercialization; develop special programs for women and youth to empower them to access credit, 
land and appropriate technology and encourage the involvement of youth in the dairy value chain development to promote succession planning and enhance commercialization.

\section{Conflict of Interests}

The authors have not declared any conflict of interests.

\section{REFERENCES}

Agwu NM, Anyanwu Cl, Mendie El (2013). Socio-Economic Determinants of Commercializing among Smallholder Farmers in Abia State, Nairobi.4th International Conference of the African Association of Agricultural Economists, September 22-25. Hammermet, Tunisia.

Amoako KY (2003). Harnessing Technologies for Sustainable Development in Africa. International Livestock Research Institute (ILRI), Addis Ababa.

Boogaarda BK, Oostinga SJ, Bock BB (2006). Socio-cultural issues of dairy production systems in the Netherlands assessed through farm visits with citizen panels. Wageningen Institute of Animal Sciences, Wageningen University, EAAP 2006, Session L1: Ethics of Sustainability: Book of abstracts Theatre 6. P 3.

Cefer A, Riggs K, Mubichi F, Sandler L (2014). Socio-cultural perspectives on Agricultural Development within a Sub-Saharan African context: Paradigm shift and interdisciplinary engagement: University of Missouri, Columbia. Agrarian frontiers 2:1.

Ele IE, Omini GE, Adinya BI (2013).Assessing the extent of Commercialization of Smallholding Farming Households in Cross River State, Nigeria. J. Agric. Vet. Sci. 4(3):49-55.

Farinde AJ, Taiwo KA (2003). Moving women from subsistence to commercialization. Issues and policy imperatives. Paper presented at the workshop organised by FAO/ IITA on the gender impact of the commercialization of smallholder Agriculture. Institute for International Tropical Agriculture, Ibadan May 14-16.

Gebreselassie S, Sharp K (2008). Commercialization of smallholder agriculture in selected Tef-growing areas of Ethiopia. Agriculture and rural development division, Ethiopian Economic Policy Research Institute (EEPRI), Addis Ababa, Ethiopia.

Government of Kenya (GoK) (2010a). Kenya National Dairy Master Plan, Nairobi

Government of Kenya (GoK) (2013a). UasinGishu County Annual Report. Ministry of Agriculture, Livestock and Fisheries, Eldoret.112p.

Government of Kenya (GoK) (2013b). Sessional Paper No 5 of 2013 on National Dairy Development Policy. Government Printer, Nairobi.

Government of Kenya (GoK). (2013c). County Integrated Development Plan; UasinGishu County, Eldoret, Kenya.

Hall JF (2005). Introduction to Economics, 2nd Edition. South Western Thomson Learning

Heierli U, Gass T (2001). Enhancing employment and income generation in rural areas. Paper submitted to the Operation Committee of the Swiss Agency for development and cooperation (DEZA). Available at: www.deza.admintheman.
IFAD (International Fund for Agriculture Development) (2015). Smallholder Dairy Commercialization Programme Additional Financing: Updated Programme Design Report. IFAD, Rome. 54p.

Jaleta M, Gebremedhin B, Hoekstra D (2009). Smallholder Commercialization: Processes, Determinants and Impact. Discussion Paper No. 18. Improving Productivity and Market Success (IPMS) of Ethiopian Farmers Project, ILRI (International Livestock Research Institute), Nairobi, Kenya. $55 \mathrm{p}$.

Jayne TS, Haggblade S, Minot N, Rasid S (2012). Agricultural commercialization, rural transformation and poverty reduction. Synthesis report prepared for the African agricultural Markets Programme Policy Symposium Alliance for Commodity Trade in Eastern and Southern Africa. April 20-22, Kigali, Rwanda.

Kibiego M, Lagat J, Bebe B (2015). Competitiveness of Smallholder Milk Production Systems in Uasin Gishu County of Kenya. J. Econ. Sustain. Dev. 6(10):39-45.

Kurosaki T (2003). Specialization and diversification in Agricultural transformation. The case of west Punjab, 1903-92. Am. J. Agric. Econ. 85(2):372-386.

Lapar ML, Holloway G, Ehui S (2003). Policy options promoting market participation among smallholder livestock producers: Case study from the Philippines. Food Policy 28:187-211.

Manfre C, Rubin D, Allan A, Summerfield G, Colverson K, Akeredolu M (2013). Reducing the Gender gap in Agricultural Extension and advisory services: How to find the best fit for men and women farmers. Modernising extension and advisory services.Brief 2.

Muhammad-Lawal A, Amolegbe KB, Oloyede WO, Lawal OM (2014). Assessment of Commercialization of food crops among farming households in Southwest, Nigeria. Department of Agricultural Economics and Farm Management, University of Ilorin, P.MB 1515 , Ilorin, Nigeria. Ethiopian J. Environ. Stud. Manage. 7(5):520-531.

Nmadu JN, Iwuajoku RC, Jiya EZ (2012).Commercialization level of poultry production in Minna Metropolis, Niger state, Nigeria. Asian J. Agr. Ext. Econ. Sociol. 1(1):1-15.

Ochola WO, Muhia RN, Mwarasomba LI (2003). Culture, Traditions and Society: The Challenges to Natural Resource Management and Development. National Soil and Water Conservation Programme/Swedish International Development Agency (SIDA), Nairobi.

Omiti J, McCullough E, Otieno D, Madelon M, Nyanamba T, Murage A (2006). Participatory Prioritization of Issues in Smallholder Agricultural Commercialization in Kenya. KIPPRA Discussion Paper No. 64. $72 \mathrm{p}$.

Poulton C, Poulton C, Leavy J (2008). Commercialization in Agriculture. Ethiopian J. Econ. 16(1):3-42.

Randela R, Alemu ZG, Groenewald JA (2008). Factors enhancing market participation by small-scale cotton farmers. Agrekon South Afr. 47(4):451-469

Simonyan JB, Olukosi JO, Omolehin RA (2010). Socio-economic determinants of farmers participation in Fadama II Project in Kaduna State, Nigeria. J. Food Fiber Prod. 1:592-601.

Tangka F, Ouma EA, Staal SJ, Shapiro B (1999). Women and Sustainable Development of Market-Oriented Dairying Evidence from East Africa.ILRI in collaboration with MOA and KARI, Nairobi.

Zhou S, Minde IC, Mtigwe B (2013). Smallholder Agricultural Commercialization for Income Growth and Poverty Alleviation in Southern Africa: A Review. Afr. J. Agric. Res. 8(22):2599-2608. 